\title{
REGULATION OF ETHYL ACETATE FRACTION FROM MORINGA OLEIFERA LEAVES TO IMPROVE LIPID METABOLISM AND INSULIN SENSITIVITY IN TYPE 2 DIABETES
}

\author{
SHOLIHATIL HIDAYATI ${ }^{1}$, RINI SULISTYAWATI ${ }^{1}$, LAELA HAYU NURANI ${ }^{2}$ \\ ${ }^{1}$ Academy of Food and Pharmaceutical Analyses Al-Islam Yogyakarta, Gedongkiwo MJ I/816, 55142, Yogyakarta, Indonesia, ${ }^{2}$ Department \\ of Biology Pharmacy, Faculty of Pharmacy, Ahmad Dahlan University, Jl. Prof. Soepomo Janturan, 55165, Yogyakarta, Indonesia \\ Email: sholihatilhidayati@yahoo.co.id
}

Received: 08 Jun 2018 Revised and Accepted: 03 Sep 2018

\section{ABSTRACT}

Objective: Moringa oleifera is a medicinal plant species that has potential as an antidiabetic. The present study was designed to evaluated molecullar mechanism antidiabetic ethyl acetate fraction of Moringa oleifera leaves (EAFML).

Methods: The study was conducted on 30 male wistar rats which were induced with the combination of streptozotocin and nicotinamide by intraperitoneal administration to make a model of type 2 diabetes. After the diabetic induction, all rats were divided into six group and once daily administered orally EAFML in doses standardized quercetine. The treatment was given for ten days, and on the final treatment, all rats were checked their blood glucose level and lipid profile. The skeletal muscles and liver were taken to examine glucose transporter-4 (GLUT4) expression by immunohistochemistry.

Results: The result of this study shows that the blood glucose level in diabetic rats with the treatment of EAFML decreased significantly from $355.8 \pm 83.7 \mathrm{mg} / \mathrm{dL}$ to $177.5 \pm 89.3 \mathrm{mg} / \mathrm{dL}$. The cholesterol decreased significantly from $105.2 \pm 47.4 \mathrm{mg} / \mathrm{dL}$ to $58.6 \pm 6.9 \mathrm{mg} / \mathrm{dL}$ and low-density lipoprotein (LDL) in diabetic rats with the treatment of EAFML decreased significantly compared to control group from $175.6 \pm 41.9 \mathrm{mg} / \mathrm{dL}$ to $95.3 \pm 8.0 \mathrm{mg} / \mathrm{dL}$. The expression of GLUT4 in skeletal muscles increased from $0.7 \pm 1.0$ to $3.9 \pm 1.1$ and in the liver increased significantly from $1.8 \pm 1.3$ to $2.9 \pm 1.9$.

Conclusion: The EAFML can decrease blood glucose level, cholesterol and low-density lipoprotein in type 2 diabetic rat model. Other than that, this fraction can improve insulin sensitivity by the increase of GLUT4 expressions.

Keywords: Ethyl acetate, GLUT4, Moringa oleifera, Type 2 diabetes

(C) 2018 The Authors. Published by Innovare Academic Sciences Pvt Ltd. This is an open access article under the CC BY license (http://creativecommons.org/licenses/by/4.0/) DOI: http://dx.doi.org/10.22159/ijpps.2018v10i10.27845

\section{INTRODUCTION}

Type 2 diabetes is a progressive disease characterized by hyperglycemia with insulin resistance in early condition. Insulin resistance is a reduction of the response of insulin target cells and tissues to a physiological concentration of insulin. This condition is caused by abnormalities of metabolism such as metabolic stress syndrome, obesity, high blood pressure, high blood lipids, high blood uric acid and diabetes [1]. Type 2 diabetes with insulin-resistant especially marked by a defect in glucose uptake because it associated with regulation of GLUT4 protein. The expression of GLUT4 gene is subject to both tissue-specific and hormonal/ metabolic regulation. GLUT4 plays a critical role in glucose-sensing although only $15 \%$ of the blood glucose is absorbed by adipose tissue and the remaining (85\%) by muscle in healthy individual [2]. Insulin induces translocation of GLUT4 from intracellular vesicles to the plasma membrane, which permits the facilitated diffusion of circulating glucose down its concentration gradient into muscle cells leading to a rapid increase in the uptake of glucose. Accumulating evidence indicates that either expression deregulation or functional impairment of GLUT4 can cause insulin resistance. Because of its crucial role, GLUT4 has been considered to be a potential therapeutic target for type 2 diabetes [3].

Some plants are shown to have antidiabetic effects, one of which is Moringa oleifera leaves [4]. Moringa oleifera is a medicinal plant species that has potential as an antidiabetic [5]. Moringa oleifera is rich in phytochemical compounds such as flavonoids, alkaloids, and saponins [6]. Flavonoid is one of the biologically active class of secondary metabolite plant compounds that belong to an important part of human diet. The antidiabetic properties of flavonoids are mainly through their effect on a number of molecular targets and regulation of several pathways such as reducing apoptosis, improving proliferation of pancreatic beta cell and promoting insulin secretion, regulation of glucose metabolism in hepatocytes and subsequent improvement of hyperglycemia, decreasing insulin resistant, inflammation and oxidative stress in adipocytes and skeletal myofibers, enhancing glucose uptake in skeletal and adipose tissues [2].

Based on these reviews, Moringa oleifera leaves have the potential to be developed as an antidiabetic agent. However, it is not yet known whether the active component has an effect as an antidiabetic and molecular mechanism. Thus, it is important to study the antidiabetic effect of EAFML and molecular mechanism study.

\section{MATERIALS AND METHODS}

\section{Material}

Streptozotocin (STZ) was purchased from Nacalai tesque, INC (Kyoto, Japan), Nicotinamid (Sigma-Aldrich, USA). Glucose level was measured by using colorimetric metode (GOD-PAP) with glucose oxidase and 4aminoantipyrine (DiaSys, Diagnostic System GmbH, Holzheim, Germany). Lipid profile was measured by enzimatic photometric methods using kit from DiaSys, Diagnostic System GmbH, Holzheim, Germany. Antibodies for determining of GLUT4 expression were a primary anti-GLUT4 antibody (Santa Cruz Biotechnology, California, USA). All other reagents were high-grade qualified material.

\section{Preparation of EAFML}

Moringa oleifera leaves were collected from the area of Gunung Kidul, Yogyakarta special region, Indonesia. The leaves were shade dried, powdered and store in airtight container for further use. The plant was authenticated with certificate number 029/lab. Bio/B/III/2017 by a botanist at the Department of Biology Pharmacy, Faculty of Pharmacy, Ahmad Dahlan University, Indonesia. The dried powder of Moringa oleifera leaves was subjected to extractor by maceration using $80 \%$ ethanol for $3 \mathrm{~d}$ and was re-extracted using the same solvent for $4 \mathrm{~d}$. All 
liquid extracts were collected and concentrated using a rotary vacuum evaporator under reduced pressure. The extract fractionated with nhexane and the water-soluble fraction is purified with ethyl acetate and obtained ethyl acetate fraction.

\section{Preparation of type 2 diabetic rat model}

The animal model handling protocols of this study were in accordance with the guidelines of the animal care of the Departement of Pharmacology, Faculty of Pharmacy, Ahmad Dahlan University, Indonesia. 30 male wistar rats were acclimatized for $1 \mathrm{w}$ and housed in individual cages at a constant temperature $\left(22 \pm 2{ }^{\circ} \mathrm{C}\right)$ with a constant relative humidity $(55 \pm 10 \%)$, controlled lighting $12: 12 \mathrm{~h}$ light-dark cycle (light on at 6:00 a. m) and had free access to food and water ad libitum. The rats were previously exited before being induced fasted with administering nicotinamide $100 \mathrm{mg} / \mathrm{kg}$ insulin solution by intraperitoneal (i. p). 15 min followed by injection of STZ in doses of 65 $\mathrm{mg} / \mathrm{kg}$ (i. p) in $0.1 \mathrm{M}$ buffer citrate, $\mathrm{pH} 4.5$ made new. The control group was injected with a citrate buffer. After $5 \mathrm{~d}$, the animal was measured for their fasting blood glucose level (BGL). BGL $\geq 200 \mathrm{mg} / \mathrm{dL}$ fall into the positive category of diabetes. The methodology of this experiment was performed after the approval by Research Ethics Committee Ahmad Dahlan University with ethical approval number 021703005.

\section{Antidiabetic treatment of EAFML}

A total of 30 rats were used and divided into 6 groups with 5 rat per group. Group I (control, a healthy rat). Group II (negative control, an untreated diabetic rat). Group III (positive control, a diabetic rat with metformin treatment in doses of $100 \mathrm{mg} / \mathrm{kg}$ once daily orally). Group IV, V and VI (treatment groups 1, 2 and 3, a diabetic rat with EAFML treatment in doses of $12.5 ; 25$ and $50 \mathrm{mg} / \mathrm{kg}$ once daily orally). Treatment was carried out for $10 \mathrm{~d}$. On the 10th day, all the rats were fasted and measured their BGL and lipid profile.

\section{Histology of skeletal muscle and liver}

The rats were sacrificed at the end of the treatment and the skeletal muscle and liver tissue of control and treated groups were taken and fixed with $4 \%$ formaldehyde in phosphate buffer. The tissues were embedded in paraffin and cut into pieces of the desired size and then the tissues were deparaffinized in xylane then dehydrated of alcohol concentration. The sections were then stained with HematoxylinEosin (HE) and observed using a light microscope with a magnification of $1000 x$.

\section{Expression of GLUT4 by immunohistochemistry}

Sections of skeletal muscle and liver organ were collected and fixed with $4 \%$ formaldehyde solution in the phosphate-saline buffer for more than $2 \mathrm{~h}$. Then the tissue was hydrated with concentrated alcohol, then cleaned using xylol. The tissue was immersed in paraffin and cut with a thickness of $4 \mu \mathrm{m}$ and placed on a glass slide. Endogenous peroxidase activity in the tissue was blocked with $3 \%$ $\mathrm{H} 2 \mathrm{O} 2$ in methanol for $15 \mathrm{~min}$ and washed with aqua dest. The tissue portion was incubated with $20 \%$ horse serum for more than $10 \mathrm{~min}$, subsequently reincubated with GLUT-4 primary antibody with 1 : 250 dilution for one hour at room temperature, followed by incubation peroxidase-conjugate secondary antibody with 1: 500 dilution for 1 hour. Visualization was performed after incubation with the substrate for $15 \mathrm{~min}$, and the section was counterstained with Hematoxylin for $30 \mathrm{~min}$, hydrated with alcohol and xylene. The evaluation of protein expression was calculated based on semiquantitative methods according to the modified Remmele method. Immunoreactive score (IRS) or Rammele scale index is the result of multiplication between the percentage score of immunoreactive cells with color intensity score on immunoreactive cells. The end result obtained ranges from $0-12$ points [7].

\section{Statistical analysis}

Statistical analysis used SPSS 17.0 with a confidence level of 95\%. The date from an examination of blood glucose level and lipid profile was presented in chart table, then it's was normalitis tested by using sapiro-wilk, and the homogenity was tested by using Leven's Test of Homogeneity of Varian test. The average difference of each component was analyzed statistically by one-way ANOVA. Differences of GLUT4 expression between groups were analyzed with the Kruskal-Wallis test and followed by Mann-Whitney test.

\section{RESULTS}

\section{Observation of blood glucose level in pre-treatment}

On day-1, the rats were injected intraperitoneally with nicotinamide in doses of $100 \mathrm{mg} / \mathrm{kg}$ in normal saline. After $15 \mathrm{~min}$, the rats were given an intraperitoneal injection with STZ in doses of $65 \mathrm{mg} / \mathrm{kg}$. bw in citrate buffer to induce diabetes. BGL was measured on day-5. Rats with diabetes were those that have BGL>200 mg/dL [2]. The data of BGL before and after induction can be seen in table 1 .

Tabel 1: Blood glucose level in pre-treatment

\begin{tabular}{llll}
\hline Group & $\boldsymbol{\Sigma}$ & \multicolumn{2}{l}{ Blood glucose level $\mathbf{( m g / \mathbf { d L } )}$} \\
\cline { 2 - 4 } & & $\mathbf{H}-\mathbf{1}$ & $\mathbf{H - 5}$ \\
\hline Control & 5 & $64.7 \pm 11.7$ & $105.0 \pm 13.5$ \\
Diabetes & 25 & $70.1 \pm 11.7$ & $493.5 \pm 122.9^{*}$ \\
\hline
\end{tabular}

${ }^{*}$ Data of BGL on day- 5 significantly different from day- $1(\mathrm{p}<0.05)$, Data represent mean \pm SD

The BGL of induced rats on day- 5 increased significantly from $70.1 \pm 11.7 \mathrm{mg} / \mathrm{dL}$ to $493.5 \pm 122.9 \mathrm{mg} / \mathrm{dL}$ with $\mathrm{p}<0.05$. It showed that the combination of nicotinamide injection and STZ injection was able to improve BGL significantly compared with the control group on day-5.

\section{Observation of BGL in post-treatment}

After diabetes induction using the combination of STZ dan nicotinamide, the diabetic rats divided into 5 groups and given treatment for $10 \mathrm{~d}$. On day-11 of post-treatment, the rats' BGL were checked. The result of BGL in post-treatment is presented in table 2.

Tabel 2: Blood glucose level in post-treatment

\begin{tabular}{ll}
\hline Groups & Blood glocose level of post-treatment (mg/dL) \\
\hline Control & $84.1 \pm 18.7$ \\
Diabetes & $355.8 \pm 83.7^{*}$ \\
Diabetes+metformin $100 \mathrm{mg} / \mathrm{kg}$ & $258.8 \pm 175.9^{*}$ \\
Diabetes+EAFML $12.5 \mathrm{mg} / \mathrm{kg}$ & $313.2 \pm 19.5^{*}$ \\
Diabetes+EAFML $25 \mathrm{mg} / \mathrm{kg}$ & $337.2 \pm 124.2^{*}$ \\
Diabetes+EAFML $50 \mathrm{mg} / \mathrm{kg}$ & $177.5 \pm 89.3$ \\
\hline
\end{tabular}

*significantly different from the control group with $\mathrm{p}<0.05$, Data represent mean \pm SD 
Table 2 shows there are no significant differences between the BGL of diabetic rats with EAFML treatment in doses of $50 \mathrm{mg} / \mathrm{kg}$ for $10 \mathrm{~d}$ and the BGL of the healthy group. It shows that the administration of EAFML in doses of $50 \mathrm{mg} / \mathrm{kg}$ improved BGL significantly.

\section{Observation of lipid profile in post-treatment}

Lipid profile observations were performed on day-11 of posttreatment. The lipids that were analyzed included cholesterol, triglycerides, LDL and HDL. Lipid profile data can be seen in table 3.

Table 3: Lipid profile in post-treatment

\begin{tabular}{lllll}
\hline \multirow{2}{*}{ Groups } & Lipid profile (mg/dL) & & \\
\cline { 2 - 5 } & Cholesterol & TG & LDL & HDL \\
\hline Control & $75.0 \pm 7.3$ & $62.2 \pm 19.6$ & $134.2 \pm 11.7$ & $71.7 \pm 9.1$ \\
Diabetes & $105.2 \pm 47.4$ & $51.0 \pm 22.1$ & $175.6 \pm 41.9$ & $80.6 \pm 18.0$ \\
Diabetes+metformin & $72.8 \pm 10.6$ & $52.0 \pm 9.3$ & $133.7 \pm 20.8$ & $71.3 \pm 11.6$ \\
Diabetes+EAFML $12.5 \mathrm{mg} / \mathrm{kg}$ & $73.4 \pm 23.1$ & $57.2 \pm 13.7$ & $124.5 \pm 40.5$ & $62.5 \pm 15.7$ \\
Diabetes+EAFML $25 \mathrm{mg} / \mathrm{kg}$ & $58.6 \pm 6.9^{*}$ & $65.0 \pm 14.9$ & $95.3 \pm 8.0^{*}$ & $49.7 \pm 3.0^{*}$ \\
Diabetes+EAFML $50 \mathrm{mg} / \mathrm{kg}$ & $73.0 \pm 13.3$ & $36.4 \pm 11.3$ & $134.3 \pm 29.3$ & $68.6 \pm 15.0$ \\
\hline
\end{tabular}

*significantly different from the diabetic group with $\mathrm{p}<0.05$, data represent mean $\pm S D$

Based on observation of lipid profile in post-treatment, it can be seen that the diabetic group with administration of EAFML in doses of $25 \mathrm{mg} / \mathrm{kg}$ is significantly different from the diabetic group. This shows that the administration of EAFML in doses of 25 $\mathrm{mg} / \mathrm{kg}$ can significantly decrease cholesterol, triglyceride and HDL levels.
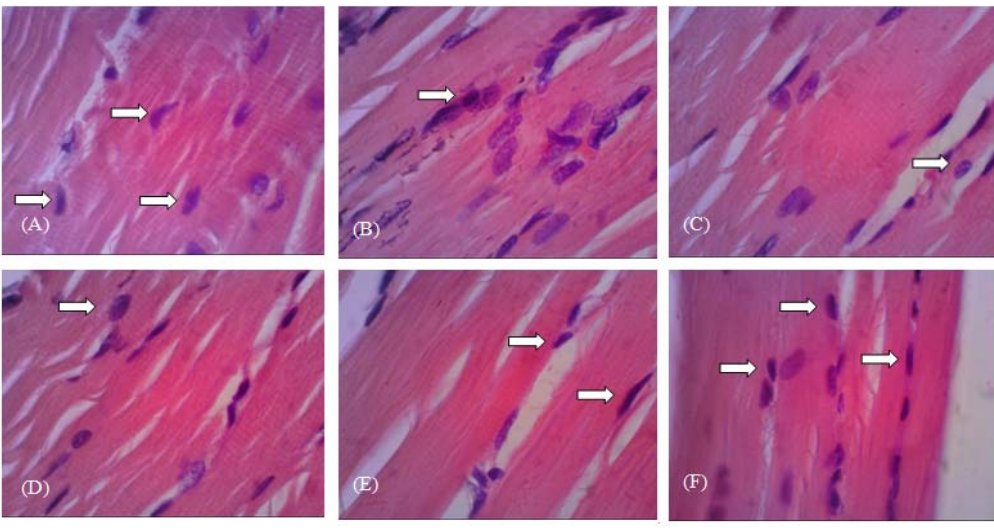

Fig. 1: Cross-section of skeletal muscle tissues with HE staining in 1000x magnification, (A) Control; (B) Diabetes; (C) Diabetes+metformin; (D) Diabetes+EAFML 12.5 mg/kg; (E) Diabetes+EAFML 25 mg/kg; (F) Diabetes+EAFML 50 mg/kg
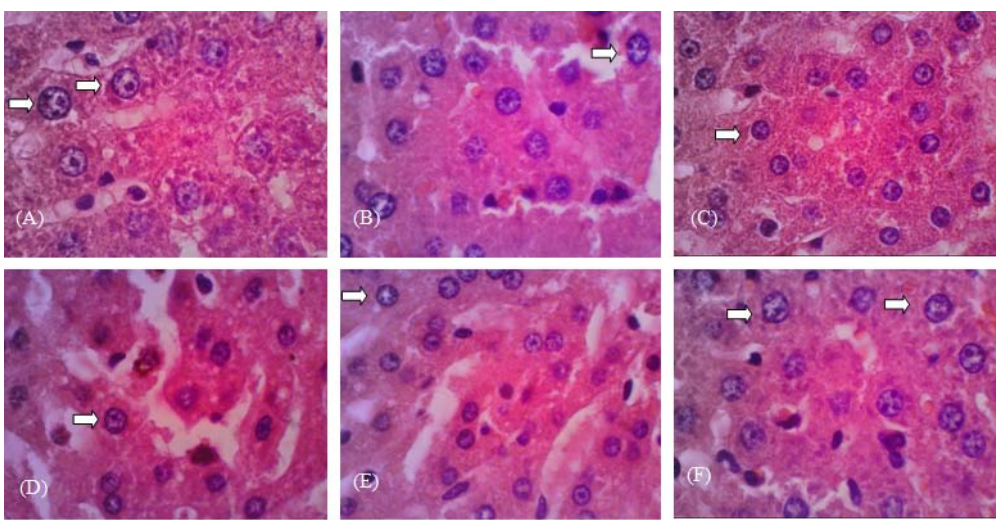

Fig. 2: Cross-section of liver tissues with HE staining at 1000x magnification, (A) Control; (B) Diabetes; (C) Diabetes+metformin; (D) Diabetes+EAFML 12.5 mg/kg; (E) Diabetes+EAFML 25 mg/kg; (F) Diabetes+EAFML 50 mg/kg

\section{Histology of skeletal muscle and liver tissue}

Based on histologic observation with HE staining from cross-section of skeletal muscle and liver organs of rats as seen in fig. 1 and fig. 2 , it was obtained that in normal rats the cell nuclei and hepatocytes are intact and clear (드), whereas in diabetic rats the cell nuclei had undergone necrosis which is indicated by less clear and non-intact cell shapes. After administration of EAFML in doses of $12.5 \mathrm{mg} / \mathrm{kg}$; $50 \mathrm{mg} / \mathrm{kg}$ and $50 \mathrm{mg} / \mathrm{kg}$, it can be seen that the cell nuclei had improved, in which the number of cell nuclei that were intact and that had clear color increased.

\section{GLUT4 expression in skeletal muscle and liver}

Molecular observation had been undergone to see the expression of the GLUT4 protein on skeletal muscle and liver organs using immunohistochemistry method. GLUT4 is one of the parameters of the occurrence of insulin resistance. Changes of GLUT4 protein level which influenced glucose tolerance have been proven on a transgenic animal 
with GLUT4 protein deficiency and play roles in insulin resistance condition; thereby, therapy with a target on the increase of GLUT4 protein expression is a new breakthrough in discovering a new antidiabetic medication [8].

The observations were performed under a light microscope with 400x magnification. If in cells there is found GLUT4 protein expression, the brown color will be seen on the cytoplasm. Mayer Hematoxylin was used as a counterstain for examination of GLUT4. Immunohistochemical features for GLUT4 protein expression can be seen in fig. 3 and 4 .

The observation result of immunohistochemical of GLUT4 protein in muscle and liver can be seen in table 4.

Table 4: Expression of GLUT4 in skeletal muscle and liver in post-treatment

\begin{tabular}{ll}
\hline Groups & GLUT4 expression \\
\cline { 2 - 2 } & Skeletal muscle \\
\hline Control & $3.4 \pm 2.3^{*}$ \\
Diabetes & $0.7 \pm 1.0$ \\
Diabetes+metformin & $2.6 \pm 1.6^{*}$ \\
Diabetes+EAFML $12.5 \mathrm{mg} / \mathrm{kg}$ & $2.2 \pm 1.0^{*}$ \\
Diabetes+EAFML $25 \mathrm{mg} / \mathrm{kg}$ & $2.2 \pm 1.5^{*}$ \\
Diabetes+EAFML $50 \mathrm{mg} / \mathrm{kg}$ & $3.9 \pm 1.1^{*}$ \\
\hline
\end{tabular}

*significantly different from the diabetic group with $\mathrm{p}<0.05$, Data represent mean \pm SD
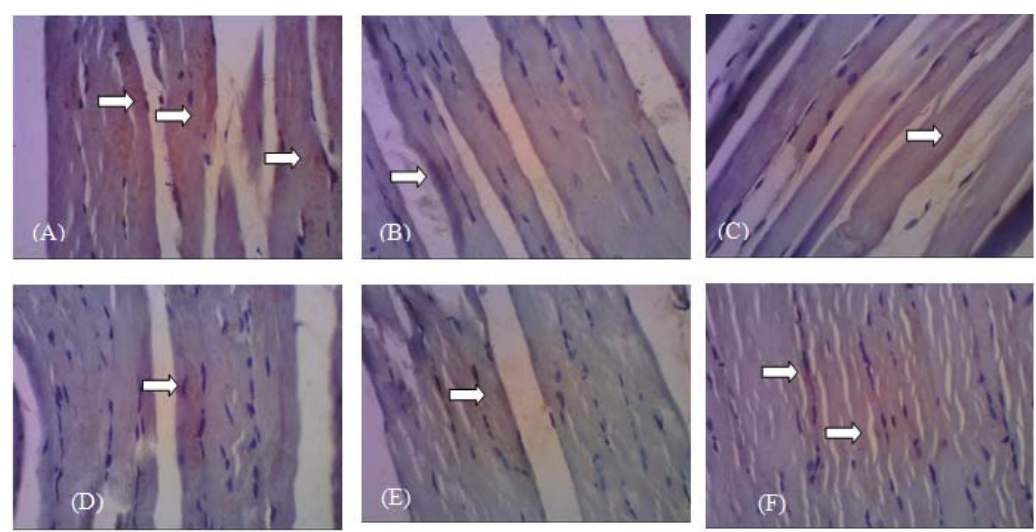

Fig. 3: Immunohistochemical staining results of experimental animals' skeletal muscle tissues using GLUT-4 antibody, (A) Control; (B) Diabetes; (C) Diabetes+metformin; (D) Diabetes+EAFML 12.5 mg/kg; (E) Diabetes+EAFML 25 mg/kg; (F) Diabetes+EAFML 50 mg/kg; Magnification 400x
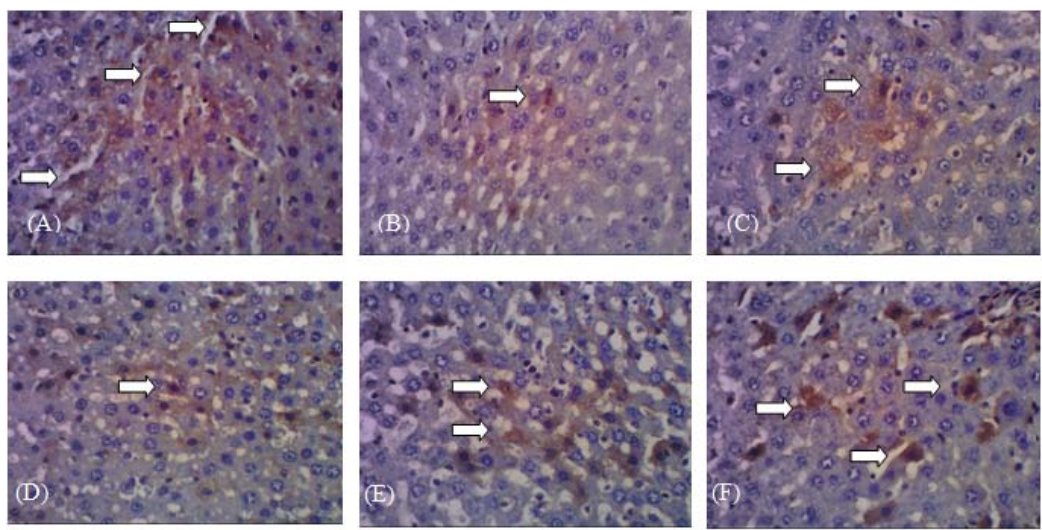

Fig. 4: Immunohistochemical staining results of experimental animals' liver tissues using GLUT-4 antibody, (A) Control; (B) Diabetes; (C) Diabetes+metformin; (D) Diabetes+EAFML $12.5 \mathrm{mg} / \mathrm{kg}$; (E) Diabetes+EAFML $25 \mathrm{mg} / \mathrm{kg}$; (F) Diabetes+EAFML 50 mg/kg; Magnification 400x

Based on fig. 3. Immunohistochemical Results, GLUT4 expression is indicated by dark brown spots $\Leftrightarrow \Rightarrow$ ). From the pictures, it can be seen that from the administration of EAFML at the dosage of $12.5 \mathrm{mg} / \mathrm{kg}$; $50 \mathrm{mg} / \mathrm{kg}$ and $50 \mathrm{mg} / \mathrm{kg}$, GLUT4 expression increased which was indicated by the increased of the number of brown color and the color is more dense.

\section{DISCUSSION}

In this study, type 2 diabetes induction was done to make the combination of STZ and nicotinamide. Induction of STZ and nicotinamide in rat model of type 2 diabetes is based on the protective effects of nicotinamide against $\beta$-cytotoxic effects of STZ. This model is as a model for non-obese type 2 diabetes [9].

Based on this study, it showed that the ethyl acetate fraction of Moringa oleifera leaves has potential as antidiabetic agent. Several studies related to the effects of Moringa oleifera leaves as antidiabetes have been performed. The observation of in vitro assay with clonal of pancreatic beta cells of BRIN-BDII showed that acetone extract of Moringa oleifera leaves had an insulinotropic effect through $\mathrm{K}_{\mathrm{ATP}}$-dependent pathway indicated by the increased 
of intracellular $\mathrm{Ca}^{2+}$ level [10]. Another in vivo study proved that Moringa oleifera leaves extract significantly increased the activity of superoxide dismutase (SOD) and glutathione-s-transferase (GST), and decreased lipid peroxidase (LPO), which is a characteristic factor in chronic diabetes [11]. The antidiabetic evaluation of methanol extract of Moringa oleifera leaves was proven can decrease blood glucose levels of rat and showed antioxidant activity with the decreased the level of nitric oxide (NO) serum [12]. Another study also suggested that water extract of Moringa oleifera leaves had a hypoglycemic effect through normalization of the increase of hepatic pyruvate carboxylase enzyme and regeneration of hepatocyte and pancreatic beta cells damages [13].

The result of phytochemicals Moringa oleifera leaves are polyphenols, flavonoids, saponins and alkaloids [14]. Another study suggested that the phytochemical content of Moringa oleifera leaves includes: 4-(4'-oacetyl-alpha-ramnopiranoyloxy) benzyl isothiocyanate, benzyl isothiocyanate [15], total polyphenols, quercetin, kaempferol, and lutein [16], quercetin-3-glycosides (isoquersitrin), quercetin-4glycosides (spiraeosid), chlorogenic acid [17].

These regulation of flavonoids as antidiabetic in many cases may be direct i.e. mediated by the physical interaction of a receptor (specific enzyme) and the flavonoid compound and may lead to either inhibition or activation of the catalytic function of the enzyme. In addition, natural polyphenols show less specific antioxidant ability of hydroxyl groups linked to aromatic carbon rings [2].

In this study, immunohistochemical tests were performed to see GLUT4 expression. The GLUT4 expression spread to the skeletal muscle, adipose tissue, liver, kidney, and pancreas [18]. In the basal condition, GLUT4 is mostly located in intracellular organelles and in order to move to the surface of the cell membrane, requires a signal from insulin. The expression of some forms of glucose transporter on the surface of the cell plays a role in glucose uptake, signal regeneration, and metabolism to maintain the body's cellular metabolic integrity [19]. This study found that administration of EAFML can increase the expression of GLUT4. This is similar to another study that show curcumin increased expression of GLUT4, in which curcumin is one of the polyphenols similar to flavonoid [20].

The influence of EAFML on lipid profile indicated that this fraction can decrease cholesterol and triglycerides. The mechanism might have a correlation to the ability of flavonoids which are the main secondary metabolites of EAFML bound to pectin. Flavonoid cooperation with pectin can work at the level of intestine and liver to stimulate fat excretion and reduce fat absorption, which augments the direct activity on enzymes, involved in the regulation of carbohydrate and lipid metabolism [21].

\section{ACKNOWLEDGMENT}

This study was supported by The National Competitive Research Grant from KEMENRISTEK DIKTI, Indonesia.

\section{AUTHORS CONTRIBUTIONS}

All the author have contributed equally

\section{CONFLICT OF INTERESTS}

\section{Declared none}

\section{REFERENCES}

1. Yu J, Zheng J, Liu XF, Feng ZL, Zhang XP, Cao LL, Zhou ZP. Exercise improved lipid metabolism and insulin sensitivity in rats fed a high-fat diet by regulating glucose transporter 4 (GLUT4) and muscalin expression. Braz J Med Biol Res 2016;49:1-6.
2. Hajiaghaalipour F, Khalilpourshbafi M, Arya A. Modulation of glucose transporter protein by dietary flavonoids in type 2 diabetes mellitus. Int J Biol Sci 2015;11:508-24.

3. Zhao FQ, Keating AF. Functional properties and genomics of glucose transporters. Curr Genomics 2007;8:113-28.

4. Mamun-or-Rashid ANM, Hossain S, Hassan N, Dash BK, Sapon A, Sen MK. A review on medical plants with antidiabetic activity. J Pharmacog Phytochem 2014;394:149-59.

5. Sugunabai J, Jayaraj M, Karpagam T, Varalakshmi B. Antidiabetic efficiency of Moringa oleifera and Solanum nigrum. Int J Pharm Pharm Sci 2014;6:40-2.

6. Abalaka ME, Daniyan SY, Oyeleke SB, Adeyemo S. The antibacteria evaluation of moringa oliefera leaf extract on selected bacterial pathogens. J Microbiol Res 2012;2:1-4.

7. Nowak M, Mabej JA, Dziegiel P. Intensity of COX2 expression in cells of soft tissue fibrosacrcomas in dogs as related to grade of tumour malignancy. Bull Vet Inst Pulawy 2007;51:275-9.

8. Huang S, Czech MP. The GLUT4 glucose transporter. Cell Metab 2007;5:237-52.

9. Ghasemi A, Khalifi S, Jedi S. Streptozotocin-nicotinamideinduced rat model of type 2 diabetes. Acta Physiol Hungarica 2014;101:408-20.

10. Ojo OO dan Ojo CC. Insulinotropic action of Moringa oleifera involves the induction of membrane depolarization and enhancement of intracelullar calcium concentration. J Exp Integr Med 2014;5:36-41.

11. Jaiswal D, Rai PK, Mehta S, Chatterji S, Shukla S, Rai DK. Role of Moringa oleifera in regulation of diabetes-induced oxidative stress. Asian Pacific J Trop Med 2013;6:423-6.

12. Gupta R, Mathur M, Bajaj VK, Katariya P, Yadav S, Kamal R, et al. Evaluation of antidiabetic and antioxidant activity of Moringa oleifera in experimental diabetes. J Diab 2012;4:164-71.

13. Abd El Latif A, El Biaiy Bel S, Mahboub HD, Abd El Daim MA. Moringa oleifera leaf extract ameliorates alloxan-induced diabetes in rats by regeneration of $\beta$-cells and reduction of pyruvate carboxylase expression. Biochem Cell Biol 2014;92:413-9.

14. Sulistyawati R, Nuraini LH, Hidayati S, Mursydi A, Mustofa. Standarization of quality from ethyl acetate fraction of Moringa oleifera leaves. In: The $6^{\text {th }}$ University Research Colloquium. Muhamadiyah magelang University. Magelang 9 September. [Indonesia]; 2017.

15. Fahey JW. Moringa oleifera: a review of the medical evidence for its nutritional, therapeutic, and prophylactic properties. J Trees Life 2005;1:5.

16. Ramakrishnan BS, Venkataraman R. Screening of antioxidant activity, total phenolics and gas chromatography massspectrophotometer (GC-MS) study of ethanolic extract of Aporosa lindleyana. Afr J Res 2011;5:360-4.

17. Ndong M, Uehara M, Katsumata S, Suzuki K. Effects of oral administration of Moringa oleifera Lamk. on glucose tolerance in goto-kakizaki and wistar rats. J Clin Bioc Nutr 2007;40:229-33.

18. Kristensen T, Fredholm M, Cirera S. Expression study of GLUT4 translocation-related genes in a porcine pre-diabetic model. Mamm Genome 2015;26:650-7.

19. Kobayashi H, Mitsui T, Nomura S, Ohno Y, Kadomatsu K Muramatsu T, Nagasaka $\mathrm{T}$, et al. Expression of glucose transporter 4 in the human pancreatic islet of langerhans. Biochem Biophys Res Commun 2004;314:1121-5.

20. Moradi A, Bahrami M, Eslami G, Mohiti Ardekani J. The effect of curcumin on GLUT4 gene expression as a diabetic resistance marker in C2C12 myoblast cells. IJDO 2014;6:96-105.

21. Janda E, Lascala A, Martino C, Ragusa S, Nucera S, Walker R, et al. Molecular mechanisms of lipid-and glucose-lowering activities of bergamot flavonoid. Phanu 2016;4:S8-S18. 